\title{
Rec.: MIRKO BREITENSTEIN, JULIA BURKHARDT, STEFAN BURKHARDT, JENS RÖHRKASTEN (EDS.), RULES AND OBSERVANCE. DEVISING FORMS OF COMMUNAL LIFE
} (VITA REGULARIS ORDNUNGEN UND DEUTUNGEN RELIGIOSEN LEBENS IM MITTELALTER, ABHANDLUNGEN 60), BERLIN 2014, S. 303 + 7 NLB. LIT VERLAG

Omawiana praca zawiera studia zaprezentowane w ramach trzech paneli poświęconych średniowiecznemu monastycyzmowi na Międzynarodowym Kongresie Mediewistycznym w Leeds w 2012 r. Składa się ze wstępu (s. VII-X), 13 artykułów (s. 3-294), listy autorów (s. 295) i indeksu geograficzno-osobowego (s. 297-303). Całość poprzedzają uwagi wstępne redaktorów tomu, omawiające jego główne założenia. Zawarte w pracy artykuły zgrupowano w czterech działach tematycznych, ukazujących problem: tworzenia, egzekwowania, przekazywania oraz symbolicznego przedstawiania norm i reguł monastycznych. Autorzy poszczególnych opracowań zastanawiali się nad znaczeniem przestrzegania norm (observantia) jako warunku niezbędnego dla poprawnego funkcjonowania wspólnoty monastycznej oraz rozważań na temat tej kwestii w piśmiennictwie zakonnym i codziennej praktyce.

Część pierwszą, zatytułowaną Creation of Norms, otwiera studium, którego autorem jest Nicholas W. Youmans, Non sic erit fratres. Internal Structures of Obedience in Early Minorite Relational Constructs (s. 3-42). Wychodząc od rozumienia terminu posłuszeństwo (obediencia) w życiu monastycznym, autor przedstawił problem posłuszeństwa regule i przełożonym zakonnym w praktyce franciszkańskiej. Analizując najstarsze teksty (Regula non bullata, Regula bullata, testament św. Franciszka, Expositio Quatuor Magistrorum) pod-

„Nasza Przeszłość” t. 131: 2019, s. 267-273. 
kreślił, że rozumienie posłuszeństwa w zakonie zostało ostatecznie wypracowane w procesie jego instytucjonalizacji. Zwieńczeniem były w tym zakresie konstytucje z Narbonne, które stawiały na dyscyplinę i podporządkowanie przełożonym, zgodnie z zasadą hierarchiczną Kościoła. Stan ten utrwalał stały obowiązek odczytywania treści konstytucji we wszystkich konwentach.

W kolejnym artykule Anna Campbell, St Colette of Corbie and The friars 'of the bull'. Franciscan Reform in Fifteenth Century France (s. 43-66) przedstawiła reformę części franciszkanów francuskich wprowadzoną za sprawą starań Kolet z Corbie. Dążąc do reformy wspólnot klarysek, pośrednio wymuszała ona zmiany w sprawujących nad nimi opiekę duszpasterską wspólnotach franciszkańskich. Było to możliwe dzięki wsparciu papieża, który zezwolił jej na wybór braci, którzy pełnili opiekę nad zreformowanymi siostrami. Doprowadziło to do powstania we Francji dwóch grup zreformowanych franciszkanów: koletanów i obserwantów. W drugiej połowie XV w. toczyły się spory o podporządkowanie koletanów obserwantom i prawo do sprawowanie przez obserwantów opieki duszpasterskiej nad wspólnotami koletanek, które rządziły się własnymi konstytucjami zatwierdzonymi przez papieża. W konkluzji autorka stwierdza, że oddziaływanie reformy Kolet jako wzorca reformy dla franciszkanów było dość ograniczone.

Ostatnie studium w tym dziale napisał Nicolangelo D'Acunto, $\mathrm{Ca}$ maldolese Settlements. Hermitages and Monasteries as Sites of Conflict between Different Projects of Religious Life (s. 69-75). Autor przedstawił proces przemian jakim podlegała w okresie średniowiecza wspólnota kamedułów. W XIII i XIV w. wbrew pierwotnej praktyce eremickiej, nowe siedziby zakonu lokalizowano często w miastach. W konsekwencji wymusiło to zmiany w wewnętrznym funkcjonowaniu wspólnoty. Pierwotne życie eremickie w wielu miejscach ustąpiło bardziej popularnemu cenobityzmowi. W XV w. pojawił się wyraźny opór wobec kierunku tych zmian i silne dążenie powrotu do form pierwotnych. W efekcie tych działań w XVI w. nastąpiło odnowienie ideałów eremickich. Manifestacją tego procesu była architektura nowych klasztorów. Ich wygląd wprost nawiązywał do pierwszej siedziby w Camaldoli traktowanej od tego czasu jako swoisty wzorzec. Nowobudowane klasztory, tak jak w początkach funkcjonowania wspólnoty, lokalizowano znów z dala od miast. 
Część druga książki, zatytułowana Enforcing Norms, zawiera trzy studia. W pierwszym Bert Roest, Sub humilitatis titulo sacrum scientiam abhorrentes. Franciscan Observants and the Quest for Education (s. 79-106), nawiązując do swych wcześniejszych badań, podjął ponownie problem stosunku franciszkanów obserwantów do kształcenia zakonników ${ }^{1}$. Wskazał na początkowo negatywne nastawienie obserwantów do edukacji, widzianej jako zagrożenie dla ideału ubóstwa i życia wspólnotowego w zakonie. W szczegółowych analizach przedstawił poglądy Bernarda ze Sieny na problem przygotowania do kaznodziejstwa i studiów oraz organizację odrębnego nauczania wypracowaną przez obserwantów niezależnie od konwentuałów. Odniósł się również do organizacji systemu szkolnego przez koletanów (reforma obserwancka we Francji) i martynianów (franciszkanów zreformowanych w Niemczech w oparciu o konstytucje papieża Marcina V). Osobno omówił również nurt eremicki wśród obserwantów franciszkańskich w Hiszpanii, w tym tak zwaną reformę w Villacreciana w Kastylii. W podsumowaniu autor podkreśla, że stopniowo nastąpiło przewartościowanie w stosunku obserwantów do edukacji, przygotowując nowych kaznodziejów docenili oni rolę studiów, czego dowodem było też objęcie przez nich szeregu studiów generalnych zakonu.

Dwa kolejne artykuły poświęcono problemowi rozumienia zasady posłuszeństwa w praktyce funkcjonowania franciszkanów. W pierwszym Jens Röhrkasten, Franciscan Obedience and Disobedience in Practice (s. 107-128) wychodząc od zasady dobrowolnego ubóstwa sformułowanej przez św. Franciszka prześledził rozwój rozumienia problemu posłuszeństwa we wczesnej fazie kształtowania się ruchu franciszkańskiego i relacji pomiędzy teorią a praktyką w życiu zakonnym. Podkreślił znaczenie tekstów normatywnych, tworzonych przez kapituły generalne i prowincjalne, oraz zasadniczą zmianę wynikającą z przekształcenia w latach 40-tych XIII w. początkowo niedużej wspólnoty w wielką strukturę zakonną. Zwieńczeniem tego etapu były konstytucje z Narbonne. Pierwotne rozumienie zasady posłuszeństwa zastąpiła hierarchiczna organizacja wspólnoty. Rozpatrując praktyczne formy realizacji zasady posłuszeństwa autor odwołał się do sposobu rozstrzygania sporów o podłożu etnicznych, z jakimi spotykał się zakon na Śląsku i w Irlandii. Te i inne problemy wymagały wprowa-

${ }^{1}$ B. Roest, A History of Franciscan education (c. 1210-1517), Leiden-Boston-Köln 2000. 
dzenia standardowych rozwiązań. W podsumowaniu podkreśla, że znaczenie pierwszorzędne miały regularnie odbywane kapituły generalne i prowincjalne zakonu. Te drugie miały nie tylko przekazywać decyzje kapituł generalnych na poziom prowincji, ale jednocześnie działać bardziej elastycznie, stosownie do lokalnych uwarunkowań.

$\mathrm{Z}$ kolei Amanda Power w artykule zatytułowanym: The Problem of Obedience among the English Franciscans (s. 129-167) przedstawiła kwestię rozumienia zasady posłuszeństwa w zakonie franciszkanów na przykładzie Anglii. Odwołała się w tym celu do listów Adama z Marsh, collationes Tomasza z Eccleston i pism Rogera Bacona. Całość zagadnienia rozpatrzyła $\mathrm{w}$ czterech ujęciach: 1 - posłuszeństwa w rozumieniu reguły, 2 - indywidualnego posłuszeństwa braci w praktyce pierwszych lat istnienia wspólnoty, 3 - posłuszeństwa zakonników wobec czynników poza zakonem (biskupi i papież), 4 - ograniczeń w zasadzie posłuszeństwa. W konkluzji stwierdziła, że wymienieni autorzy pisząc o posłuszeństwie w różnym stopniu odwoływali się do wzoru samego św. Franciszka. Często czynił to jedynie Tomasz z Eccleston.

W części zatytułowanej Transfer of Norms umieszczono łącznie cztery studia. W pierwszym Stefan Burkhardt, Monasteries as 'laboratories of time' (s. 171-182) ukazał praktyczne znaczenie zasady podziału czasu dla organizacji życia klasztoru. Omówił kolejno: ideę czasu, jego rolę w zarządzaniu życiem wspólnoty i urządzenia mierzące. W życiu klasztornym mierzenie czasu związane było z odmawianiem liturgii godzin. Zdaniem autora zegar stał się w XIII w. standardowym wyposażeniem klasztoru. Sygnałem podziału czasu obowiązującego w życiu klasztoru był dźwięk dzwonu.

Problemowi recepcji traktatu De institutione novitorum w kolejnych dwóch stuleciach po jego napisaniu swój tekst poświęcił Mirko Breitenstein, The Success of Discipline. The Reception of Hugh of St Victor's De institutione novitiorum within the $13^{\text {th }}$ and $14^{\text {th }}$ century (s. 183-222). Kontynuując wcześniejsze badania autor poszukiwał odniesień do wybranych elementów wspomnianego traktatu u innych autorów, specjalnie analizując odwołania do pojęcia dyscypliny ${ }^{2}$. Wskazał na takie nawiązania w traktatach napisanych przez Wincen-

\footnotetext{
${ }^{2}$ M. B re it e n s te i n, Das Noviziat im hohen Mittelalter. Zur Organisation des Eintrittes bei den Cluniazensern, Cisterziensern und Franziskanern (Vita regularis. Abhandlungen 38), Berlin 2008.
} 
tego z Beauvais, Wilhelma Perault, Humberta z Romans, Wilhelma z Tournai, Jana z Walii, Bernarda z Bessa i Tomasza z Irlandii. Z przeprowadzonych analiz wynika, że tekst Hugona doczekał się wielu odniesień, komentarzy i przeróbek w pismach autorów wywodzących się ze środowisk klasztornych, kościelnych i świeckich. Przy czym szczególnie popularny był wśród autorów z zakonów mendykanckich (dominikanów i franciszkanów), którzy często wykorzystywali go jako materiał do kazań.

W trzecim artykule zamieszczonym w tej części pracy Coralie Zermatten, The Change of Propositum within the Carmelite Order. Considerations on the Eremitic Dimension in a Mendicant Order (s. 223238) przedstawiła problem zmiany modelu funkcjonowania zakonu karmelitów, która dokonała się w drugiej połowie XIII w. W okresie gdy pierwotnie eremicka wspólnota kontemplacyjna, przekształciła się pod wpływem warunków zewnętrznych (utrata siedzib w Ziemi Świętej i przymusowe przeniesienie się zakonników do miast europejskich) w zgromadzenie mendykanckie, nakierowane na duszpasterstwo. Autorka zwróciła uwagę na próbę połączenia dawnej tradycji zakonu (reguła św. Alberta - charyzmat eremicki) z nową identyfikacją wspólnoty, w której ważną rolę odgrywało zarówno nawiązanie do proroka Eliasza jako symbolicznego założyciela zakonu, jak i aktywność zakonników w życiu intelektualnym, realizowana poprzez edukację i bliskie związki z uniwersytetami.

W ostatnim artykule zamieszczonym w tej części Florent Cygler, Le rayonnement des constitutions dominicaines au XIII siècle: quelques brèves observations (s. 239-250) sformułował uwagi na temat problemu organizacji wspólnoty dominikanów i szczególnej roli ich konstytucji zakonnych jako wzorca dla wielu innych wspólnot mendykanckich. Podkreślił znaczenie dwóch elementów w organizacji struktury zakonu. Z jednej strony ścisłej organizacji hierarchicznej wspólnoty, wyrażonej we władzy przełożonego (generał, prowincjałowie, przeorzy), z drugiej zaś czynnika kontrolującego w postaci kapituł konwentu, prowincji i kapituły generalnej. Wzajemna zależność tych dwóch elementów, władzy jednoosobowej i przedstawicielstwa wspólnoty w postaci kapituł, zapewniała zakonowi odpowiednią funkcjonalność organizacyjną.

Czwarta część zbioru studiów nosi tytuł: Symbolism of Norms. Otwiera ją artykuł, którego autorem jest Jörg Sonntag, Obedience 
in High Medieval Monastic sources. Some Brief Remarks in Light of Ritual (s. 253-264). Autor skupił się na ukazaniu na kilku przykładach zasady posłuszeństwa i znaczeniu siły symbolu zawartego w wypracowanych w życiu monastycznym rytuałach. Rozumienie posłuszeństwa zakonnego przedstawione zostało poprzez odwołanie do rytuału intronizacji opata w Cluny, obmywania w sobotni wieczór nóg braciom w klasztorach benedyktyńskich i zwyczajów praktykowanych w klasztorach w związku ze śmiercią zakonnika. W konkluzji autor wskazał na pewną gradację w zasadzie posłuszeństwa, której odbiciem była lekka i ciężka wina za jej złamanie.

W kolejnym studium Julia Burkhardt, Poverty in $13^{\text {th }}$ century Dominican writing (s. 265-280) przedstawiła uwagi na temat stosunku dominikanów do problemu ubóstwa i jego interpretacji w praktyce funkcjonowania zakonu, odwołując się do trzech kategorii źródeł: 1 - tekstów normatywnych (konstytucji zakonu), 2 - ówczesnej literatury dominikańskiej, dotykającej kwestii norm i regulacji (Tomasz z Contampiré, Stefan z Bourbon), 3 - zbiorów egzemplów - materiałów do kazań. Przeanalizowane przekazy wskazują na stałe napięcie pomiędzy normą zakonną, szczególnie zakazem przyjmowania i posiadania pieniędzy przez braci, a praktyką, wynikającą z decyzji kapituł generalnych (dyspensy) i istniejącymi potrzebami.

Całość zamyka artykuł Leonie Silberer, Medieval Monastic Architecture of the Franciscan Order. Friaries as Evidence of Written and Unwritten Rules and Ideal Perceptions (s. 281-294). Studium powstało w związku z jej pracę doktorską na temat budownictwa franciszkańskiego w Europie Środkowej, która uwzględnia również prowincję polsko-czeską zakonu ${ }^{3}$. W swym artykule omówiła problem regulacji, dotyczących wznoszenia kościołów i obiektów klasztornych przez franciszkanów. Jak podkreśla, były one na tyle ogólne, że szczególnie w przypadku budynków klasztornych pozostawiały budowniczym dużą swobodę, widoczną w poszczególnych realizacjach. Zdaniem autorki, powstające obiekty były manifestacją niepisanych reguł i dostosowywania się do lokalnych warunków. W prezentowanych

\footnotetext{
${ }^{3}$ L. S i 1 b e r e r, Domus fratrum minorum. Klosterbaukunst der konventualen Franziskaner vom 13. Jahrhundert bis zur Reformation, (,Studien zur internationalen Architektur- und Kunstgeschichte" 141), Petersberg 2016.
} 
rozważaniach autorka odwołała się do barwnych ilustracji wybranych obiektów klasztornych, głównie z terenu prowincji saskiej.

Podsumowując omawiany zbiór studiów zawiera bardzo różne spojrzenie na zagadnienie norm i reguł zakonnych oraz problem ich przestrzegania. Wprawdzie dominują w nim artykuły dotyczące mendykantów, szczególnie franciszkanów, jednak kilku autorów odwołuje się również do innych wzorców życia monastycznego. W sumie czytelnik znajdzie tu szereg studiów nawiązujących do tematyki wcześniejszych prac przywołanych autorów, będących owocem pogłębiania wieloletnich badań, jak również opracowania powstałe w związku z przygotowywanymi obecnie rozprawami doktorskimi. Wszystkie one są dowodem intensywności i szerokiego spektrum zagadnień w prowadzonych aktualnie studiach nad średniowiecznym monastycyzmem. 
